\title{
Effects of overfeeding on lipid synthesis, transport and storage in two breeds of geese differing in their capacity for fatty liver production
}

\author{
Jacques MOUROT ${ }^{\mathrm{a}}$, Gérard GUY ${ }^{\mathrm{b}}$, Philippe PEINIAU ${ }^{\mathrm{a}}$, \\ Dominique HERMIER ${ }^{c *}$
}

\author{
a UMR Système d'Élevage, Nutrition Animale et Humaine, INRA, Saint-Gilles, 35590 L'Hermitage, \\ France \\ ${ }^{\mathrm{b}}$ Station Expérimentale des Palmipèdes à Foie gras, Artiguères, INRA, 40280 Benquet, France \\ ${ }^{\mathrm{c}}$ UMR Physiologie de la Nutrition et DU Comportement Alimentaire, INRA - INA P-G, \\ 16 rue Claude Bernard, 75231 Paris Cedex 05, France
}

(Received 12 August 2005 - Accepted 24 May 2006)

\begin{abstract}
Lipid synthesis, transport, and storage were investigated in two genotypes of geese that differ in their response to overfeeding, i.e. the Landes goose, which is highly susceptible to hepatic steatosis, and the Poland goose, which is partly resistant. In control, non overfed geese of the two breeds, lipid metabolism did not differ markedly. In the liver and two adipose tissues (abdominal and subcutaneous), the lipogenic capacity, in terms of fatty acid synthesis (acetyl-CoA carboxylase and fatty acid synthase) and NADPH providing (malic enzyme and glucose-6-phopshate dehydrogenase), was very similar, as was the concentration and composition of very low density (VLDL) and high density (HDL) lipoproteins, which are plasma lipoproteins responsible for the transport of lipids from the liver towards the adipose tissue. In consequence, the lipid storage, expressed as a relative proportion and lipid content of the liver and the two adipose tissues was identical in both breeds. Therefore, under our experimental conditions, it was not possible to find any metabolic markers of lipid metabolism that could be considered a limiting factor of the further capacity for fatty liver in the overfed Poland goose. By contrast, overfeeding resulted in a dramatic enhancement of lipid synthesis (liver and adipose tissue lipogenesis), transport (VLDL and HDL concentration) and storage (relative weight and lipid content of the liver and adipose tissues). Besides, and despite food intake during overfeeding being similar in both breeds, hepatic lipogenesis was higher in the Landes goose, but did not result in a higher triglycerides (TG) concentration in plasma and VLDL. This suggests that the capacity of TG secretion remains identical in both breeds, and would explain why hepatic TG storage is so efficient in the Landes goose.
\end{abstract}

goose / fatty liver / lipoprotein / lipogenesis / overfeeding

\footnotetext{
*Corresponding author: hermier@inapg.inra.fr
} 
Résumé - Effets du gavage sur la synthèse, le transport et le stockage des lipides chez deux races d'oies différant par leur aptitude à la formation de foie gras. La synthèse, le transport et le stockage des lipides ont été étudiés chez deux génotypes d'oies différant par leur réponse au gavage, à savoir l'oie Landaise, hautement prédisposée à la stéatose hépatique, et l'oie Polonaise, partiellement résistante. Chez les oies témoins, non gavées, le métabolisme lipidique ne diffèrait pas considérablement entre les deux races. Dans le foie et les deux tissus adipeux (abdominal et sous-cutané), la capacité lipogénique, en termes de synthèse d'acides gras (acétyl-CoA carboxylase et synthase des acides gras) et d'apport de NADPH (enzyme malique et glucose-6-phosphate déshydrogénase) était très voisine, ainsi que la concentration et la composition des VLDL et des HDL, qui sont les lipoprotéines responsables du transport des lipides depuis le foie vers le tissu adipeux. En conséquence, le stockage des lipides, caractérisé par la proportion et la teneur en lipides du foie et des deux tissus adipeux, était identique dans les deux souches. Donc, dans nos conditions expérimentales, il n'a pas été possible de trouver un marqueur du métabolisme lipidique qui puisse être considéré comme un facteur limitant de la capacité à former un foie gras ultérieurement lors du gavage de l'oie Polonaise. À l'inverse, le gavage a entraîné une stimulation considérable du métabolisme lipidique en termes de synthèse (lipogenèses hépatique et adipeuse), de transport (concentration des VLDL et des HDL) et de stockage (poids relatif et de teneur en lipides du foie et du tissu adipeux). De plus, malgré un ingéré en gavage identique dans les deux races, la lipogenèse hépatique était plus élevée chez l'oie Landaise, mais ne s'accompagnait pas d'une concentration plus élevée de triglycérides (TG) dans le plasma total et les VLDL. Ceci suggère que la capacité de sécrétion des TG reste identique dans les deux races, et expliquerait pourquoi le stockage des TG par le foie est si efficace chez l'oie Landaise.

oie / foie gras / lipoprotéine / lipogenèse / gavage

\section{INTRODUCTION}

In all animal species, hepatic steatosis results from an imbalance between synthesis, secretion, and storage of triglycerides (TG) by the liver [2]. As a consequence of enhanced TG availability, lipid secretion pathways as parts of lipoproteins (very low density lipoproteins, VLDL, and high density lipoproteins, HDL) may be rapidly overwhelmed, and excess lipids (triglycerides (TG) essentially) may accumulate in the liver and cause hepatic steatosis [2]. Avian species are particularly susceptible to this phenomenon, because de novo lipogenesis from dietary carbohydrates takes place mostly in the liver rather than in the adipose tissue [27]. This is particularly true in Palmipeds in which, as in other migrating species of birds and fish, hepatic steatosis occurs spontaneously as a consequence of energy storage before migration [28]. The response to overfeeding of commercial Palmiped breeds relies therefore on a dramatic enhancement of hepatic lipogenesis by overfeeding with a carbohydrate-rich corn-based diet, as demonstrated recently in the duck [3].
Besides, the balance between lipid synthesis, storage and secretion by the liver also influences extra hepatic fattening. Indeed, in birds as in other species, TG secreted into plasma as VLDL are hydrolysed by lipoprotein lipase (LPL), which results in fatty acid uptake and metabolism (esterification or oxidation) by extrahepatic cells [16]. Because de novo lipogenesis is very limited in avian adipose tissues [27], TG of hepatic origin are responsible for the dramatic increase in adipose tissue stores during overfeeding [9].

The regulation of these pathways has been shown to depend largely on the genotype $[4,9,13,19,26,29,31]$. In France, only three genotypes of Palmipeds produce an authentic fatty liver in response to overfeeding: the Landes goose (Anser anser), the muscovy duck (Cairina moschata) and the mule duck (sire Cairina moschata $\times$ dam Anas platyrhyncos). In the goose, the existence of two breeds differing in their response to overfeeding allowed the demonstration of the role of hepatic lipid metabolism as a dominant feature of 
susceptibility to hepatic steatosis. More precisely, the Poland goose, which is bred for meat production, exhibits a less extensive hepatic steatosis than the Landes goose, together with a greater extrahepatic fattening [29]. A first study of lipid metabolism in these two breeds suggested that hepatic storage of TG in the Landes goose is facilitated by a less efficient exportation of these TG as VLDL [13]. However, further studies in which food intake during overfeeding was the same in both breeds showed that, under these conditions, VLDL concentration is identical in both breeds $[20,26]$. By contrast, the concentration of HDL, which transport phospholipids (PL) synthesised by the liver, is always lower in the Landes breed, which is indicative of a less effective PL secretion $[13,20]$. In addition, the PL composition of the liver and lipoproteins differed in the two breeds: in the Landes geese, the proportion of phosphatidylcholine (as \% of total PL) is higher in the liver and lower in VLDL and HDL than in the Poland geese. This is thought to be indicative of a better retention, in the Landes breed, of the PL necessary for cell membrane growth, and therefore for cell hypertrophy associated with TG storage during overfeeding [20]. Moreover, when overfed, the Landes geese exhibit higher specific activities of some key-enzymes of hepatic lipogenesis, such as the malic enzyme (ME) and fatty acid synthase (FAS) [26]. Therefore, the greater susceptibility of the Landes breed to fatty liver production would rely, at least partly, on a higher hepatic lipogenesis when overfed, together with a lower secretion of PL, and especially of phosphatidylcholine. Surprisingly, in control, (i.e. non-overfed geese), lipid metabolism parameters are very similar in both breeds, as concerns the composition of lipids and PL of the liver, and its fatty acid profile, as well as the plasma concentration and chemical composition of VLDL and HDL particles $[13,20]$.
It remains unclear whether (a) the hepatic lipogenic capacity of the goose is a breed-dependent feature, which is expressed independently of overfeeding; (b) adipose tissue lipogenesis, which is normally very limited in birds, contributes to lipid synthesis during overfeeding; (c) the fatty acid composition of muscle and adipose tissue reflects the changes in lipogenesis occurring in response to overfeeding. The present study was therefore designed to explore the contribution of the genetic background of the goose to the hepatic and adipose lipogenic capacity, as well as its interaction with the overfeeding process. The consequences of the interactions between genotype and overfeeding on fatty acid transport and peripheral storage were also investigated.

\section{MATERIALS AND METHODS}

\subsection{Animals and diets}

The present work was carried out in agreement with the French legislation on animal experimentation and with the authorisation of the French Ministry of Agriculture (Animal Health and Protection Directorate).

\subsubsection{Protocol 1}

Male geese of the Landes and Poland breeds (20 in each breed), hatched on the same day, were bred under natural conditions of light and temperature at the Experimental Station for Palmiped Breeding (INRA, Artiguères, France). From 0 to 22 weeks of age, they were housed collectively, then they were housed in individual cages during the overfeeding period. The experimental dietary design is reported in Table I. From 0 to 4 wks of age, they had free access to a diet containing $12.3 \mathrm{MJ}$ and $205 \mathrm{~g}$ protein per $\mathrm{kg}$ diet. From 4 to 
Table I. Experimental dietary design.

\begin{tabular}{ccc}
\hline \multicolumn{3}{c}{ Diet } \\
\hline Age (wk) & Control geese & Overfed geese \\
\hline $0-4$ & Growing ad libitum & Growing ad libitum \\
$4-19$ & Growing (restricted) from 300 to 200 g per d & Growing (restricted) from 300 to 200 g per d \\
$19-22$ & Growing (restricted) 200 g per d & Growing (released) from 200 to 700 g per d \\
$22-24$ & Growing (restricted) 200 g per d & Overfeeding ad libitum \\
\hline
\end{tabular}

Control group: 10 Landes geese and 10 Poland geese.

Overfed group: 10 Landes geese and 10 Poland geese.

22 wks, they were given a growing diet (10.9 MJ and $138 \mathrm{~g}$ protein per $\mathrm{kg}$ ). Daily intake was calculated to avoid excessive fatness. The daily amount of feed provided was $300 \mathrm{~g}$ between 4 and $5 \mathrm{wks}, 350 \mathrm{~g}$ between 5 and 7 wks, $280 \mathrm{~g}$ between 7 and 8 wks and $200 \mathrm{~g}$ between 8 and 22 wks. At 19 wks of age, ten geese of each breed began the period of "pre-overfeeding", during which the feed restriction was released progressively to increase the volume of the oesophagus and to initiate the metabolic adaptation to overfeeding. In these animals, the spontaneous feed intake reached $700 \mathrm{~g}$ in 5 days on the same diet as before. At the end of the pre-overfeeding period, they started the overfeeding period for $14 \mathrm{~d}$. They were given two meals on the first day, four meals on the second day, then six meals on the 12 subsequent days. Meals consisted of a carbohydraterich diet consisting of boiled, salted maize (14.1 MJ, $90 \mathrm{~g}$ protein, and $4.5 \mathrm{~g}$ fat per $\mathrm{kg}$ ). After cooking and addition of $0.4 \%$ waterfowl fat, the final mixture consisted of approximately $70 \%$ feed and $30 \%$ water $(9.87 \mathrm{MJ}, 63 \mathrm{~g}$ protein and $7.15 \mathrm{~g}$ lipid per kg) (Tab. II). Food intake during overfeeding was similar in both breeds $(12.7 \mathrm{~kg}$ corn in Landes geese and $12.6 \mathrm{~kg}$ corn in Poland geese). For each breed, ten geese did not start the pre-overfeeding and the overfeeding processes, but still received the growing diet ( $200 \mathrm{~g}$ per day). The animals had free access to water at all times. The last day of the overfeeding period,
Table II. Composition of the overfeeding diet.

\begin{tabular}{lcc}
\hline Salted maize & g per kg & 698 \\
Water & g per kg & 298 \\
Waterfowl fat & g per kg & 4 \\
Metabolisable energy & MJ per kg & 9.87 \\
Protein & $\%$ & 6.30 \\
Lipid & $\%$ & 0.71 \\
\hline
\end{tabular}

all birds were deprived of feed overnight with water provided. The morning after, $10 \mathrm{~mL}$ blood was withdrawn by puncture of the occipital venous sinus, collected on EDTA (diNa salt) $1.2 \mathrm{~g}$ per $\mathrm{L}$ in a vacuum tube, and kept at $4{ }^{\circ} \mathrm{C}$ during the subsequent procedures. Individual plasma samples were separated by centrifugation at $2000 \mathrm{~g}$-force and $4{ }^{\circ} \mathrm{C}$ for $20 \mathrm{~min}$. Sodium azide and EDTA (diNa salt) were added as antibacterial agents to plasma samples at final concentrations of 0.1 and $0.8 \mathrm{~g}$ per L, respectively. Samples were frozen at $20{ }^{\circ} \mathrm{C}$ until further analyses.

Immediately after blood sampling, the geese were killed in a slaughterhouse by exsanguination while under electronarcosis. A $5 \mathrm{~g}$ sample was immediately taken from the ventromedial portion of the main lobe (right lobe) of each liver, the abdominal adipose tissue, and the two elements of the filet (Pectoralis major (P. major) muscle and the part composed of the skin plus subcutaneous adipose tissue (SCAT)). Theses samples were frozen in liquid nitrogen and stored at $-80{ }^{\circ} \mathrm{C}$ before determination 
of enzymatic activities. The corresponding carcasses were then kept at $4{ }^{\circ} \mathrm{C}$ overnight before dissection.

\subsubsection{Protocol 2}

Fatty acid composition of various body compartments was determined on another group of overfed geese (23 in each breed). Rearing and overfeeding conditions were the same as above, with the exception that the geese started the pre-overfeeding period at 22 weeks of age (instead of 19 weeks in protocol 1). Samples from blood, abdominal adipose tissue and the two elements of the filet were taken, treated and stored as in Protocol 1.

\subsection{Analyses}

\subsubsection{Body and tissue composition}

After carcasses were kept at $4{ }^{\circ} \mathrm{C}$ overnight, representative body compartments were dissected and weighed: liver, abdominal adipose tissue, filet and its two elements (muscle $P$. major and the part composed of the skin plus SCAT). Tissue samples were then stored at $-20{ }^{\circ} \mathrm{C}$.

Protocol 1. Liver and muscle P. major were characterised for dry matter and lipid content. Dry matter content was determined gravimetrically from a $1 \mathrm{~g}$ sample before and after heating at $105^{\circ} \mathrm{C}$ for $12 \mathrm{hrs}$ [1]. Total lipids were estimated from another sample (5 $\mathrm{g}$ for control geese and $3 \mathrm{~g}$ for overfed geese) after extraction according to the procedure of Folch et al. [11] for TG-poor tissues (liver of control geese, muscle $P$. Major in both groups) or with petroleum ether (boiling point $40-60{ }^{\circ} \mathrm{C}$ ) in a Soxhlet apparatus for TG-rich tissues (liver of overfed geese and adipose tissues of control and overfed groups).

Protocol 2. For all tissues, total lipids were extracted according to the procedure of Folch et al. [11]. The dry residue was dissolved in $5 \mathrm{~mL}$ of chloroform/methanol $(9 / 1 \mathrm{v} / \mathrm{v})$ and stored at $-20{ }^{\circ} \mathrm{C}$. Fatty acid methyl esters were prepared by derivatisation in methanol $/ \mathrm{H}_{2} \mathrm{SO}_{4}$ (95:5) of lipid extracts of VLDL, abdominal adipose tissue, and the two filet components [33]. Then they were separated and identified by gas chromatography on a Fisons 8000 chromatograph (ThermoQuest, Les Ulis, France) equipped with a BPX70 fusedsilica capillary column ( $25 \mathrm{~m}$ length, 0.22 $\mathrm{mm}$ internal diameter, $0.5 \mu \mathrm{m}$ film thickness) (SGE Europe, Courtaboeuf, France). The vector gas was helium N55 (purity: $\mathrm{H}_{2} \mathrm{O}<3$ ppm, $\mathrm{O}_{2}<2$ ppm, $\left.\mathrm{C}_{\mathrm{n}} \mathrm{O}_{\mathrm{m}}<0.5 \mathrm{ppm}\right)$ (Air liquide, Joué-les-Tours, France). The oven temperature was programmed from $150{ }^{\circ} \mathrm{C}$ to $205{ }^{\circ} \mathrm{C}$ at $2{ }^{\circ} \mathrm{C}$ per min, and that of the injector and the detector at $250{ }^{\circ} \mathrm{C}$. Injection volume was $0.3 \mu \mathrm{L}$, with a split ratio of $1 / 30$. The mixtures of standard fatty acids were obtained from Sigma (Saint-Quentin Fallavier, France).

\subsubsection{Lipogenic enzymes}

Activities of the lipogenic enzymes were determined in the liver, the abdominal adipose tissue, and the two components of the filet (Pectoralis major muscle and SCAT). Weighed quantities of tissues were homogenised in $0.25 \mathrm{M}$ sucrose and centrifuged at $40000 \mathrm{~g}$ for $40 \mathrm{~min}$. Supernatants were analysed for ME (EC 1.1.1.40) and glucose-6-phosphate dehydrogenase (G6PDH, EC 1.1.1.49) using modifications [14] of the methods of Fitch et al. [10] and Hsu and Lardy [21] respectively. NADPH formation was measured at $37{ }^{\circ} \mathrm{C}$ by absorbance at $340 \mathrm{~nm}$. AcetylCoA carboxylase (ACX, EC 6.4.1.2) was assayed by the $\mathrm{H}^{14} \mathrm{CO}_{3}$-fixation method [6, 7]. FAS (EC 2.3.1.85) was measured as described in the method of Lavau et al. [22]. NADPH oxydation was measured at $35^{\circ} \mathrm{C}$ by absorbance at $340 \mathrm{~nm}$. One unit of 
enzyme activity corresponded to $1 \mu$ mole of NADPH oxidised per minute. ME, G6PDH, and FAS activities were expressed as micromoles of NADPH produced or used per min per total liver and mg of protein. ACX activity was expressed as nmol bicarbonate incorporated per min per total liver and $\mathrm{mg}$ of protein.

\subsubsection{Plasma lipids and lipoproteins}

Lipoproteins were isolated from plasma on the basis of their hydrated density in a single step according to the ultracentrifugal gradient procedure described by Chapman et al. [8] and modified by Hermier et al. [17]. Ultracentrifugation was performed in a Beckman (Gagny, France) L855 ultracentrifuge using a Beckman SW41 rotor at $40000 \mathrm{rpm}\left(19.4 \times 10^{5} \mathrm{~g}\right)$ for $48 \mathrm{~h}$ at $15{ }^{\circ} \mathrm{C}$. Volumes and density limits of the successive lipoprotein classes were those determined previously: VLDL, $0.5 \mathrm{~mL}, \mathrm{~d}<1.013 \mathrm{~g}$ per $\mathrm{mL}$; IDL+LDL, $3.5 \mathrm{~mL}, 1.013<\mathrm{d}<1.044 \mathrm{~g}$ per $\mathrm{mL}$; HDL, $5 \mathrm{~mL}, 1.044<\mathrm{d}<1.183 \mathrm{~g}$ per $\mathrm{mL}[13]$. These lipoprotein fractions were dialysed in Spectrapor (Spectrum Medical Industries, Los Angeles, USA) tubing (molecular mass cut-off 12000-14000) for $48 \mathrm{~h}$ at $4{ }^{\circ} \mathrm{C}$ against a solution containing $0.05 \mathrm{M}$ $\mathrm{NaCl}, 0.005 \mathrm{M} \mathrm{NH}_{4} \mathrm{HCO}_{3}, 0.08 \%$ EDTA (diNa salt), and $0.01 \%$ sodium azide at $\mathrm{pH}$ $7.4(60 \mathrm{~mL}$ of lipoprotein fractions in $5 \mathrm{~L}$ dialysis solution, changed after $24 \mathrm{~h}$ ).

The following components were quantified in each lipoprotein fraction and in whole plasma as follows: proteins by the Lowry method using bovine serum albumin as a standard [25]; TG, total cholesterol and PL by colorimetric enzymatic methods, using the kits provided by Bio-Mérieux (Marcy-l'Étoile, France) and free cholesterol (FC) using the kit provided by Boehringer Mannheim (Meylan, France) $[12,30,32]$. Analyses were performed in duplicates. The amount of cholesteryl esters (CE) was calculated using the formula: $\mathrm{CE}=$ (total cholesterol FC) $\times 1.67$. In this calculation, it was assumed that the factor for the ratio of the average molecular weight of goose plasma $\mathrm{CE}$ to that of the molecular weight of free cholesterol (i.e., 1.67) was the same in humans and geese. Lipoprotein concentrations were calculated by adding the concentrations of the individual protein and lipid components.

\subsubsection{Statistical analyses}

The data were analysed using the Statview 4.5 program (Abacus Concept, Berkeley, CA, USA). Statistical differences between means were determined by ANOVA and the Fisher test and considered to be significant at $P<0.05$.

\section{RESULTS AND DISCUSSION}

Under our conditions, food intake during overfeeding was similar in both breeds (12.7 kg corn in Landes geese and 12.6 $\mathrm{kg}$ corn in Poland geese). In consequence, the difference observed between breeds in body composition and lipid metabolism could not be accounted for by the amount of nutrients provided.

\subsection{Growing and overfeeding performances (Tab. III)}

At the beginning of pre-overfeeding, Poland geese were heavier than Landes geese, and the difference between breeds remained until slaughtering in overfed geese as well as in controls. Whatever the breed, those destined for fatty liver production exhibited an increase in weight during pre-overfeeding, then during overfeeding, whereas control geese kept their weight constant. 
Table III. Body and tissue weights in control and overfed Landes and Poland geese.

\begin{tabular}{lccccc}
\hline & & \multicolumn{2}{c}{ Control geese } & \multicolumn{2}{c}{ Overfed geese } \\
& & Landes & Poland & Landes & Poland \\
\hline $\begin{array}{l}\text { Body weight before } \\
\text { preoverfeeding* }\end{array}$ & $\mathrm{g}$ & $5223 \pm 165^{\mathrm{a}}$ & $6220 \pm 108^{\mathrm{b}}$ & $5644 \pm 153^{\mathrm{a}}$ & $6348 \pm 208^{\mathrm{b}}$ \\
$\begin{array}{l}\text { Body weight before } \\
\text { overfeeding* }\end{array}$ & $\mathrm{g}$ & $5202 \pm 169^{\mathrm{a}}$ & $6148 \pm 112^{\mathrm{c}}$ & $5806 \pm 147^{\mathrm{b}}$ & $6801 \pm 158^{\mathrm{d}}$ \\
$\begin{array}{l}\text { Body weight after } \\
\text { overfeeding* }\end{array}$ & $\mathrm{g}$ & $5197 \pm 178^{\mathrm{a}}$ & $6011 \pm 122^{\mathrm{b}}$ & $8423 \pm 223^{\mathrm{c}}$ & $9101 \pm 143^{\mathrm{d}}$ \\
Liver & $\mathrm{g}$ & $86.0 \pm 3.2^{\mathrm{a}}$ & $89.2 \pm 2.9^{\mathrm{a}}$ & $767 \pm 28^{\mathrm{b}}$ & $409 \pm 29^{\mathrm{c}}$ \\
& $\%$ body weight & $1.48 \pm 0.03^{\mathrm{a}}$ & $1.66 \pm 0.04^{\mathrm{a}}$ & $9.10 \pm 0.20^{\mathrm{c}}$ & $4.46 \pm 0.33^{\mathrm{b}}$ \\
Abdominal adipose tissue & $\mathrm{g}$ & $156 \pm 15^{\mathrm{a}}$ & $149 \pm 15^{\mathrm{a}}$ & $493 \pm 21^{\mathrm{b}}$ & $528 \pm 21^{\mathrm{b}}$ \\
& $\%$ body weight & $2.97 \pm 0.24^{\mathrm{a}}$ & $2.45 \pm 0.20^{\mathrm{a}}$ & $5.84 \pm 0.15^{\mathrm{b}}$ & $5.84 \pm 0.19^{\mathrm{b}}$ \\
Total filet & $\mathrm{g}$ & $267 \pm 11^{\mathrm{a}}$ & $367 \pm 9^{\mathrm{b}}$ & $393 \pm 11^{\mathrm{b}}$ & $480 \pm 12^{\mathrm{c}}$ \\
& $\%$ body weight & $5.14 \pm 0.11^{\mathrm{b}}$ & $6.10 \pm 0.09^{\mathrm{c}}$ & $4.67 \pm 0.08^{\mathrm{a}}$ & $5.34 \pm 0.10^{\mathrm{b}}$ \\
P. major** & $\mathrm{g}$ & $224 \pm 9^{\mathrm{a}}$ & $308 \pm 7^{\mathrm{b}}$ & $258 \pm 9^{\mathrm{c}}$ & $320 \pm 7^{\mathrm{b}}$ \\
& $\%$ body weight & $4.31 \pm 0.10^{\mathrm{c}}$ & $5.13 \pm 0.10^{\mathrm{d}}$ & $3.07 \pm 0.10^{\mathrm{a}}$ & $3.54 \pm 0.06^{\mathrm{b}}$ \\
Skin + SCAT*** & $\mathrm{g}$ & $43.6 \pm 3.6^{\mathrm{a}}$ & $58.8 \pm 3.8^{\mathrm{b}}$ & $134 \pm 6^{\mathrm{c}}$ & $160 \pm 6^{\mathrm{d}}$ \\
& $\%$ body weight & $0.83 \pm 0.05^{\mathrm{a}}$ & $0.97 \pm 0.05^{\mathrm{b}}$ & $1.59 \pm 0.05^{\mathrm{c}}$ & $1.79 \pm 0.05^{\mathrm{d}}$ \\
\hline
\end{tabular}

Mean \pm SEM for 10 geese in each group. Values not sharing the same superscript differed significantly at $P<0.05$.

* Control geese ( $\mathrm{n}=10$ in each breed) were of the same age as overfed geese, but were not submitted to preoverfeeding and overfeeding. During these periods, they continued receiving the growing diet $(200 \mathrm{~g}$ per day). However, the naming of the different periods refers to geese destined for overfeeding; ** P. major: Pectoralis major muscle; $* * *$ SCAT: subcutaneous adipose tissue; Skin + SCAT were those covering the Pectoralis major muscle.

In control birds, and despite that the Poland geese were heavier, the liver weight and proportion were identical in both breeds, as described previously [20]. Abdominal fattening was also identical in both breeds, whereas the Poland geese (usually bred for meat production) exhibited higher muscular weight and subcutaneous fattening. Overfed geese exhibited a generalised fattening, which mainly involved the liver and the adipose tissues. As described previously [26], the liver weight and proportion were twice higher in the Landes geese than in the Poland ones. The effect of overfeeding on muscle weight was much less pronounced, which resulted in a decrease in the proportion of the $P$. $m a$ - jor muscle. However, in response to overfeeding, the $P$. major muscle of Landes geese gained absolute weight, whereas that of the Poland geese did not increase significantly. Abdominal fattening did not differ with breed in the overfed groups, whereas subcutaneous adipose tissue was heavier in the Poland breed.

\subsection{Water and lipid contents (Tab. IV)}

In control geese, as expected, liver and muscle contained water mainly, whereas adipose tissues contained lipids mainly. In the four studied tissues, water and lipid 
Table IV. Water and total lipid contents of the liver, P. major*, SCAT** and abdominal tissue in control and overfed Landes and Poland geese (\% of tissue weight).

\begin{tabular}{lcccc}
\hline & \multicolumn{2}{c}{ Control geese } & \multicolumn{2}{c}{ Overfed geese } \\
& Landes & Poland & Landes & Poland \\
\hline Water content (\%) & & & & \\
$\quad$ Liver & $70.4 \pm 0.24^{\mathrm{c}}$ & $70.0 \pm 0.25^{\mathrm{c}}$ & $36.5 \pm 0.8^{\mathrm{a}}$ & $45.6 \pm 2.0^{\mathrm{b}}$ \\
P. Major & $73.3 \pm 0.23^{\mathrm{b}}$ & $73.5 \pm 0.25^{\mathrm{b}}$ & $69.4 \pm 0.5^{\mathrm{a}}$ & $69.5 \pm 0.4^{\mathrm{a}}$ \\
SCAT & $13.5 \pm 1.8^{\mathrm{b}}$ & $12.8 \pm 1.3^{\mathrm{b}}$ & $5.41 \pm 0.36^{\mathrm{a}}$ & $4.30 \pm 0.23^{\mathrm{a}}$ \\
Abdominal adipose tissue & $2.97 \pm 0.40^{\mathrm{b}}$ & $3.59 \pm 0.50^{\mathrm{b}}$ & $1.53 \pm 0.27^{\mathrm{a}}$ & $1.64 \pm 0.28^{\mathrm{a}}$ \\
\hline Lipid content (\% fresh tissue weight) & & & & \\
Liver & $4.74 \pm 0.10^{\mathrm{a}}$ & $4.66 \pm 0.11^{\mathrm{a}}$ & $53.5 \pm 1.2^{\mathrm{c}}$ & $38.6 \pm 2.4^{\mathrm{b}}$ \\
P. Major & $5.78 \pm 0.27^{\mathrm{a}}$ & $7.12 \pm 1.04^{\mathrm{a}}$ & $8.43 \pm 0.64^{\mathrm{b}}$ & $9.22 \pm 0.65^{\mathrm{b}}$ \\
SCAT & $82.3 \pm 1.4^{\mathrm{a}}$ & $80.0 \pm 2.0^{\mathrm{a}}$ & $88.0 \pm 0.6^{\mathrm{b}}$ & $89.5 \pm 1.0^{\mathrm{b}}$ \\
Abdominal adipose tissue & $91.4 \pm 0.9^{\mathrm{a}}$ & $92.0 \pm 0.5^{\mathrm{a}}$ & $95.1 \pm 0.4^{\mathrm{b}}$ & $95.1 \pm 0.4^{\mathrm{b}}$ \\
\hline
\end{tabular}

Mean \pm SEM for 10 geese in each group. Values not sharing the same superscript differed significantly at $P<0.05$.

* P. major: Pectoralis major muscle; ** SCAT: subcutaneous adipose tissue adjacent to the P. major.

content were identical in both breeds. In response to overfeeding, all tissues lost water and were higher in lipids, and that in both breeds. Lipid accumulation was identical in both breeds for muscle and adipose tissue, whereas, as expected, hepatic steatosis was higher in the Landes geese. Interestingly, lipid content of the $P$. major muscle remained low $(<10 \%)$, thus meat from overfed geese can still be considered as a lean one. With the exception of the liver, the difference in body composition between Landes and Poland geese were essentially quantitative: in control and overfed birds, the higher weights of the $P$. major muscle of its subcutaneous adipose tissue in the Poland breed cannot be accounted for by their greater lipid content. Besides, calculations from Tables I and II indicate that the increase in total weight of the $P$. major, which was $34 \mathrm{~g}$ in the Landes geese and $12 \mathrm{~g}$ in the Poland ones (Tab. I), was not due to lipid accumulation only (9 and $18 \mathrm{~g}$, respectively). Actually, the muscle of Landes geese gained water and protein (15 and $10 \mathrm{~g}$ respectively) whereas that of Poland ones gained protein only $(8 \mathrm{~g})$.

\subsection{Lipogenic enzyme activities (Tab. V)}

\subsubsection{Control geese}

Specific activity of G6PDH and ME, which provide NADPH for fatty acid synthesis, was dramatically higher in the liver than in muscle and adipose tissues, in accordance with the fact that the liver is the main site for de novo lipogenesis in avian species [27]. Besides, in the liver and the abdominal adipose tissue, the activity of G6PDH was similar to that of ME. This was described previously in the goose $[4,5]$ and more recently in the duck [3], but is contradictory to the general assessments that, in birds, the hexose-phosphate shunt, and therefore the production of G6PDH, is not or little active, and that ME is the main source of NADPH [27]. The present study confirms that data obtained in the chicken and the pigeon cannot be extrapolated to other avian species, and especially not to migrating species that are naturally susceptible to hepatic steatosis, such as Palmipeds [28]. 


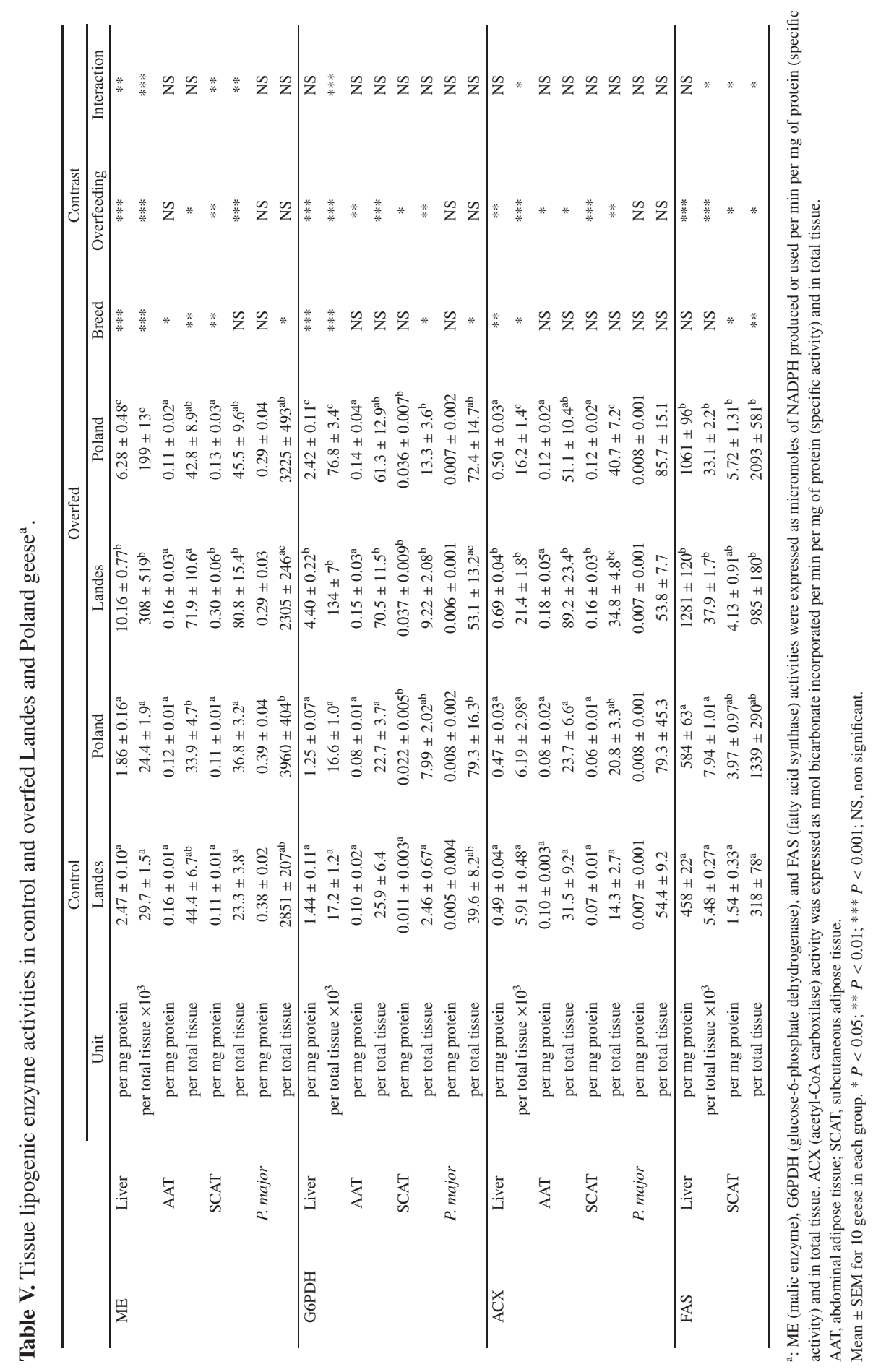


The activity of enzymes directly involved in fatty acid synthesis (ACX and FAS) was also expressed mainly in the liver. In addition, the specific activity of ACX was also detected at a significant level in the two adipose tissues, with a value accounting for $13-20 \%$ of that in the liver. By contrast, FAS specific activity was $300 \%$ lower in the subcutaneous adipose tissue than in the liver, and was therefore not determined in the abdominal adipose tissue and the $P$. major muscle. Whatever the enzyme or the tissue studied in control geese, specific or total activities did not differ significantly between the two breeds. This was in accordance with a recent study comparing four duck genotypes [3].

\subsubsection{Effect of overfeeding}

In response to overfeeding, the specific activity of all enzymes was dramatically enhanced, and that in both breeds. The response, however, differed with tissue and enzymes. The specific activities of all enzymes, and especially of ME and FAS, increased in the liver and the subcutaneous adipose tissue. In addition, they were higher in the Landes breed than in the Poland one for ME, G6PDH and ACX, but did not differ significantly with breed for FAS. The breed-related difference was more marked than in a previous study, in which only the specific activity of ME differed significantly, and was paralleled by a higher ME mRNA level in the Landes geese [26]. The hypothesis that the transcription of other genes encoding for lipogenic enzymes may be enhanced by overfeeding to a greater extent in the Landes goose remains to be demonstrated. In overfed ducks, only ACX specific activity differed between the four studied genotypes, and was the lower in the Pekin duck, which is less susceptible to hepatic steatosis [3].
In the studied adipose tissues of overfed geese, there was an increase in the specific activity of G6PDH, ACX, and FAS, which was identical in both breeds. The specific activity of ME was increased by overfeeding in the subcutaneous adipose tissue only, and not in the abdominal one. Moreover, this increased activity affected the Landes breed only. However, when compared to those in the liver, the specific and total activities of lipogenic enzymes in the two adipose tissues of overfed geese remained very low. Thus, as in control birds, their contribution to triglyceride accumulation in these adipose tissues was very limited. Finally, enzymatic activities in the $P$. major muscle, which were very low in control birds, were not modified by overfeeding. This could explain, at least partly, why TG content in the muscle remained so low after overfeeding.

\subsection{Plasma lipids and lipoproteins (Tab. VI)}

In control birds, plasma concentrations in TG, PL, and FC did not differ with the breed, whereas those in CE was slightly but significantly higher in the Poland geese. The lipoproteins studied were those transporting TG (VLDL) and those transporting mostly PL and CE (HDL). In these 24 wk-old control geese, plasma concentration and composition of lipids and lipoproteins are close to those measured in geese of the same breeds, before pre-overfeeding (13 weeks of age) [13]. Moreover, the absence of breed-related differences in non overfed geese, which was also found on the duck [18] confirms that plasma lipid and lipoproteins, and especially VLDL concentration and TG content, do not provide appropriate markers of the susceptibility to fatty liver production in response to overfeeding.

In accordance with a previous study [13], overfeeding resulted in an 
Table VI. Concentration (g per L) and composition (\%) of plasma lipids and of the main lipoproteins in control and overfed Landes and Poland geese.

\begin{tabular}{|c|c|c|c|c|c|}
\hline & & \multicolumn{2}{|c|}{ Control geese } & \multicolumn{2}{|c|}{ Overfed geese } \\
\hline & & Landes & Poland & Landes & Poland \\
\hline & & \multicolumn{4}{|c|}{ Plasma } \\
\hline Free cholesterol & g per $L$ & $0.303 \pm 0.020^{\mathrm{a}}$ & $0.317 \pm 0.021^{\mathrm{a}}$ & $0.755 \pm 0.046^{\mathrm{b}}$ & $1.089 \pm 0.095^{\mathrm{c}}$ \\
\hline Cholesteryl esters & $g$ per $\mathrm{L}$ & $1.59 \pm 0.05^{\mathrm{a}}$ & $1.87 \pm 0.09^{\mathrm{b}}$ & $4.00 \pm 0.190^{c}$ & $3.63 \pm 0.16^{\mathrm{c}}$ \\
\hline Triglycerides & $g$ per $L$ & $1.16 \pm 0.09^{\mathrm{a}}$ & $1.20 \pm 0.05^{\mathrm{a}}$ & $5.17 \pm 0.36^{\mathrm{b}}$ & $4.97 \pm 0.80^{\mathrm{b}}$ \\
\hline \multirow[t]{2}{*}{ Phospholipids } & g per $L$ & $2.37 \pm 0.08^{\mathrm{a}}$ & $2.51 \pm 0.09^{\mathrm{a}}$ & $5.61 \pm 0.22^{\mathrm{b}}$ & $6.53 \pm 0.33^{c}$ \\
\hline & & \multicolumn{4}{|c|}{ VLDL $(\mathrm{d}<1.013 \mathrm{~g}$ per $\mathrm{mL})$} \\
\hline Concentration & $g$ per $L$ & $0.70 \pm 0.11^{\mathrm{a}}$ & $0.629 \pm 0.09^{\mathrm{a}}$ & $5.14 \pm 0.31^{\mathrm{b}}$ & $5.14 \pm 0.92^{\mathrm{b}}$ \\
\hline Free cholesterol & $\%$ & $7.33 \pm 0.18^{\mathrm{a}}$ & $7.99 \pm 0.18^{\mathrm{a}}$ & $8.19 \pm 0.26^{b}$ & $9.04 \pm 0.42^{b}$ \\
\hline Cholesteryl esters & $\%$ & $20.3 \pm 0.8^{\mathrm{a}}$ & $19.4 \pm 0.8^{\mathrm{a}}$ & $11.6 \pm 1.4^{\mathrm{b}}$ & $11.1 \pm 1.1^{\mathrm{b}}$ \\
\hline Triglycerides & $\%$ & $42.7 \pm 1.2^{\mathrm{a}}$ & $41.0 \pm 1.3^{\mathrm{a}}$ & $56.1 \pm 2.0^{\mathrm{b}}$ & $51.8 \pm 1.7^{\mathrm{b}}$ \\
\hline Phospholipids & $\%$ & $19.4 \pm 0.4^{\mathrm{b}}$ & $20.7 \pm 0.5^{\mathrm{b}}$ & $17.2 \pm 0.6^{\mathrm{a}}$ & $20.0 \pm 0.6^{\mathrm{b}}$ \\
\hline \multirow[t]{2}{*}{ Proteins } & $\%$ & $10.2 \pm 0.5^{\mathrm{a}}$ & $10.9 \pm 0.4^{\mathrm{a}}$ & $6.83 \pm 0.39^{\mathrm{b}}$ & $8.08 \pm 0.31^{\mathrm{c}}$ \\
\hline & & \multicolumn{4}{|c|}{ HDL $(1.044<\mathrm{d}<1.183 \mathrm{~g}$ per $\mathrm{mL})$} \\
\hline Concentration & $g$ per $L$ & $5.21 \pm 0.31^{\mathrm{b}}$ & $5.22 \pm 0.32^{\mathrm{b}}$ & $14.1 \pm 0.5^{\mathrm{a}}$ & $14.0 \pm 0.5^{\mathrm{a}}$ \\
\hline Free cholesterol & $\%$ & $3.66 \pm 0.10^{\mathrm{c}}$ & $3.74 \pm 0.21^{\mathrm{c}}$ & $1.42 \pm 0.16^{\mathrm{a}}$ & $1.93 \pm 0.16^{\mathrm{b}}$ \\
\hline Cholesteryl esters & $\%$ & $16.6 \pm 0.8^{\mathrm{a}}$ & $15.2 \pm 0.4^{\mathrm{a}}$ & $18.8 \pm 0.6^{\mathrm{b}}$ & $16.7 \pm 0.8^{\mathrm{a}}$ \\
\hline Triglycerides & $\%$ & $5.44 \pm 0.45^{\mathrm{a}}$ & $5.73 \pm 0.51^{\mathrm{a}}$ & $7.30 \pm 0.54^{\mathrm{b}}$ & $6.72 \pm 0.53^{\mathrm{a}}$ \\
\hline Phospholipids & $\%$ & $28.8 \pm 0.4^{b}$ & $28.3 \pm 0.3^{b}$ & $26.0 \pm 0.6^{\mathrm{a}}$ & $29.1 \pm 0.6^{\mathrm{b}}$ \\
\hline Proteins & $\%$ & $45.6 \pm 0.6^{\mathrm{a}}$ & $47.1 \pm 0.5^{\mathrm{a}}$ & $46.4 \pm 0.8^{\mathrm{a}}$ & $45.5 \pm 1.0^{\mathrm{a}}$ \\
\hline
\end{tabular}

Mean \pm SEM for 10 geese in each group. Values not sharing the same superscript differed significantly at $P<0.05$.

increase in all plasma lipids. Plasma concentration was significantly increased by 2 for FC and PL, 2.5 for CE and HDL, and 80 for VLDL. VLDL of the two breeds, and HDL of the Landes geese, were significantly $25-30 \%$ richer in TG. This enrichment in TG reflected the capacity of the liver to secrete TG synthesised in response to overfeeding. In addition, the PL proportion of VLDL and HDL was significantly higher (by 12-16\%) in the Poland geese than in the Landes ones. Therefore, the Poland geese seemed to respond to overfeeding by a more intense secretion of hepatic PL, which was also reflected by a higher plasma PL concentration in this breed. These observations were in accordance with the hypothesis that an efficient exportation of PL by the liver results in an intracellular PL deficiency, which slows down membrane synthesis necessary for cellular hypertrophy, and thus steatosis [20].

\subsection{Fatty acid composition of VLDL and tissues (Tab. VII)}

\subsection{1. $V L D L$}

These lipoproteins transport mainly TG synthesised by the liver from dietary carbohydrates, and their fatty acid composition was similar to that of hepatic TG in the same breeds of geese. Thus, as described previously [20] they contained mostly oleic $(18: 1 \mathrm{n}-9, \pm 45 \%)$, palmitic $(16: 0, \pm 30 \%)$, and stearic $(18: 0,11-14 \%)$ 


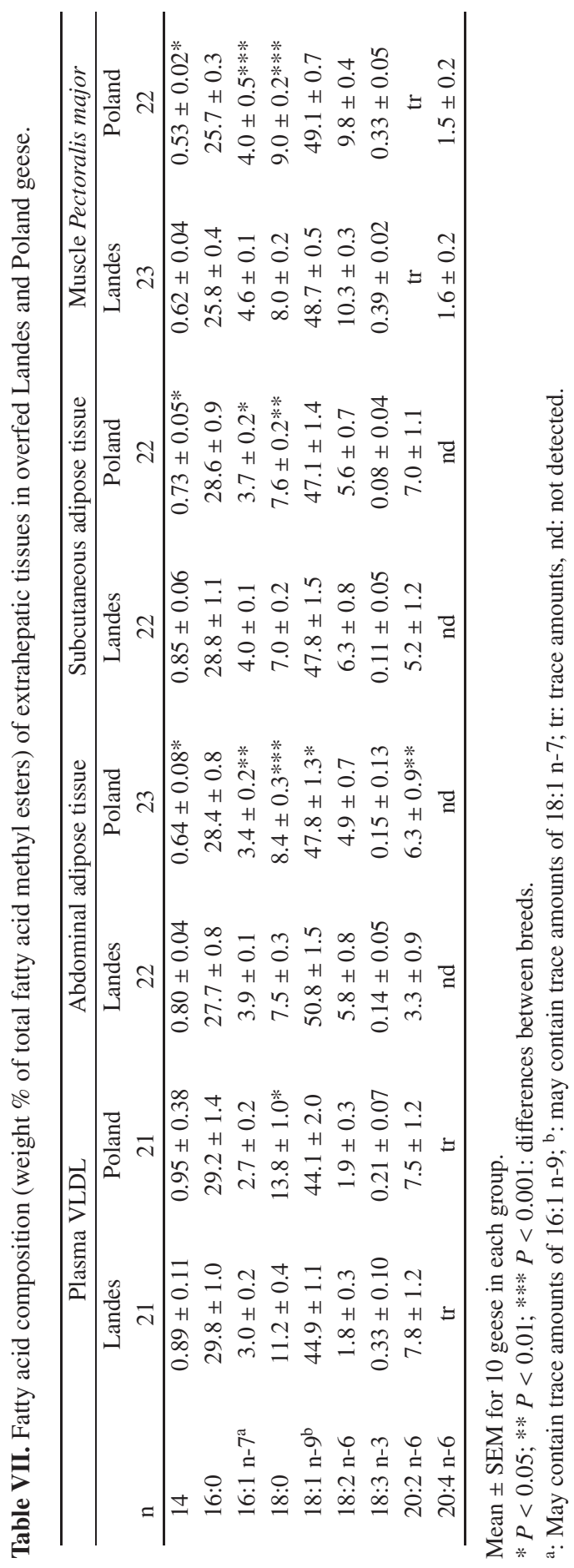


ACIDS, which are the main products of the de novo hepatic lipogenesis. In contrast, polyunsaturated fatty acids (PUFA) are essential and must be provided by the diet. In VLDL, they were mainly of the $n-6$ family and included the dietary precursor, linoleic acid (18:2 n-6) and its two longchain derivatives, 20:2 n-6 and arachidonic acid (20:4 n-6). 20:4 n-6 was present only in traces and linoleic acid accounted for less than $2 \%$ of total fatty acids, whereas it was the main fatty acid in corn $( \pm 43 \%)$. In contrast, there was a significant amount of $20: 2 n-6( \pm 8 \%)$, which results from the elongation of 18:2 n-6. This high 20:2 n6/18:2 n-6 ratio is very unusual and seems typical of the goose, since it was described previously in the VLDL of this species, but not in chicken VLDL [24]. Fatty acid composition of VLDL was very similar in both breeds. The only significant difference concerned stearic acid (18:0) which was more abundant in the Poland geese. This was in accordance with a similar difference in the 18:0 proportion in the liver TG of the two breeds, and confirmed the close resemblance between stored TG and those secreted as VLDL. Since TG account for up to $95 \%$ of hepatic lipid in overfed geese $[13,20]$, the fatty acid composition of plasma VLDL can represent a good marker of the hepatic TG and may be used to estimate, in living animals, the influence of diet and/or genotype on the fatty acid composition of the fatty liver.

\subsubsection{Adipose tissues}

Since adipose tissues in birds do not synthesise fatty acids under normal conditions [27], their fatty acid composition reflects mostly that of $\mathrm{TG}$ transported by hepatic VLDL. As in VLDL, 18:1n$9( \pm 50 \%), 16: 0( \pm 30 \%)$ and 18:0 $( \pm 8 \%)$ were thus major components. However, when compared to VLDL, both abdominal and subcutaneous adipose tissues were enriched in 18:2 n-6. This is indicative of the contribution of intestinal portomicrons that directly provided dietary PUFA. There was no difference in the fatty acid composition of the two adipose tissues studied. By contrast, the fatty acid composition was sensitive to the genetic origin, and that in both studied tissues. In the Poland goose, both tissues contained more 18:0, and less 14:0 and 16:1 n-7, and abdominal adipose tissue contained less 18:1 n-9 than in the Landes goose. Because the lower proportion of 18:0 in both adipose tissues of the Landes goose was paralleled by a higher proportion of 18:1 n-9 in the abdominal adipose tissue only (but not in subcutaneous adipose tissue or in VLDL), the contribution of hepatic delta-9 desaturation is unlikely. This is therefore different from the chicken, in which an increase in hepatic lipogenesis was paralleled by an increased hepatic delta-9 desaturase activity, which resulted in higher proportions of 18:1 n-9 in both VLDL and the liver [24]. The proportion of 20:2 n-6 tended to be higher in the Poland goose (significant in abdominal adipose tissue only), to the detriment of the 18:2 n-6 precursor. The potential role of elongases in this process is to be established, as is a possible tissue specificity.

\subsubsection{Filet}

Again, the fatty acid composition of the $P$. major muscle was close to that of VLDL. However, on the contrary to VLDL, only trace amounts of 20:2 n-6 were detected, whereas 18:2 n-6 content was 5-fold higher than in VLDL. This muscle exhibited significant amounts of 20:4 $\mathrm{n}-6$, in accordance with its high content in membrane PL, and of linoleic acid. Breedrelated differences were the same as in VLDL and in adipose tissues: filet was higher in 18:0 and lower in 14:0 and 16:1 n-7 in the Poland than in the Landes geese. 


\section{CONCLUSION}

The present data confirm that, when food intake is kept identical in Landes and Poland geese, lipid metabolism is very similar in control, non overfed geese: they did not differ markedly in the proportions and lipid content of liver and adipose tissue (i.e. lipid storage), in the concentration and composition of plasma lipoproteins (i.e. lipid transport), and in the lipogenic activity of various tissues (i.e. lipid synthesis). More specifically, the present study demonstrates for the first time in the goose that the hepatic lipogenic capacity is not a breed-dependent feature, which would be expressed independently of overfeeding. Therefore, under our experimental conditions, it was not possible to find any metabolic markers of lipid metabolism that could be considered a limiting factor of the further capacity for fatty liver production in the overfed Poland goose.

By contrast, overfeeding resulted in a dramatic enhancement of lipid synthesis (in the liver and, more surprisingly, in the adipose tissue), transport (VLDL and HDL concentration) and storage (relative weight and lipid content of liver and adipose tissues). Besides, hepatic lipogenesis was higher in the Landes goose, but did not result in a higher TG concentration in total plasma and VLDL. This suggests that the capacity of TG secretion remains identical in both breeds, and would explain why hepatic TG storage is so efficient in the Landes goose. Moreover, PL transport in response to overfeeding is less effective in this breed, in accordance with our hypothesis that PL retention in the liver favours TG accumulation [20].

In conclusion, this study indicates that lipogenic enzymes are up-regulated in response to overfeeding in both the liver and the adipose tissue, and that this regulation depends on the genetic background of the Palmipeds studied. The regulation pathways of hepatic TG metabolism, such as esterification and storage, assembly into VLDL (involvement of microsomal transfer protein) or beta-oxidation of fatty acids remain to be explored [15]. Moreover, the role of other proteins responsible for the breed-related response to overfeeding, such as those involved in PL synthesis and secretion by the liver [20] or in TG storage by the adipose tissue (LPL) [9], remains to be investigated. Specific attention should be paid to regulation by insulin, which is of particular importance in the control of lipid metabolism in birds [23].

\section{ACKNOWLEDGEMENTS}

We are pleased to acknowledge the skilful assistance of Pascal Gouraud in geese breeding and overfeeding, and the technical contribution of Solange Guillaumin. We wish to thank gratefully the CIFOG (Interprofessional Committee of Palmipedes dedicated to fatty liver production) for its financial support.

\section{REFERENCES}

[1] Dosage de l'humidité, Journal Officiel des Communautés Européennes, 1971, L279/278

[2] Alpers D.H., Sabesin S.M, White H.M., Fatty liver: biochemical and clinical aspects, Dis. Liver (1993) 825-855.

[3] Baeza E., Rideau N., Chartrin P., Davail S., Hoo-Paris R., Mourot J., Guy G., Benadet M.D., Juin H., Meteau K., Hermier D., Canards de Barbarie, Pékin et leurs hybrides : aptitude à l'engraissement, INRA Prod. Anim. 18 (2005) 131-141.

[4] Bogin E., Avidar J., Rivetz B., Israeli B., Fatty liver in fattened geese. Enzyme profile of liver and serum, Zbl. Veterinarmed A 25 (1978) 727-733.

[5] Bogin E., Avidar J., Merom M., Israeli B.A., Malkinson M., Soback S., Kudler Y., Biochemical changes associated with fatty liver in geese, Avian Pathol. 13 (1984) 683701 . 
[6] Chakrabarty K., Leveille G.A., Acetyl CoA carboxylase and fatty acid synthetase activities in liver and adipose tissue of meal-fed rats, Proc. Soc. Exp. Biol. Med. 131 (1969) 1051-1054.

[7] Chang H.C., Seidman I., Teebor G., Lane M.D., Liver acetyl CoA carboxylase and fatty acid synthetase: relative activities in the normal state and in hereditary obesity, Biochem. Bioph. Res. Co. 28 (1967) 682686.

[8] Chapman M.J., Goldstein S., Lagrange D., Laplaud P.M., A density gradient ultracentrifugal procedure for the isolation of the major lipoprotein classes from human serum, J. Lipid Res. 22 (1981) 339-358.

[9] Davail S., Rideau N., Guy G., Andre J.M., Hermier D., Hoo-Paris R., Hormonal and metabolic responses to overfeeding in three genotypes of ducks, Comparative Biochemistry and Physiology - Part A, Mol. Integrative Physiol. 134 (2003) 707-715.

[10] Fitch W.M., Hill R., Chaikoff I.L., The effect of fructose feeding on glycolytic enzyme activities of the normal rat liver, J. Biol. Chem. 234 (1959) 1048-1051.

[11] Folch J., Lees M., Sloane-Stanley G.H., A simple method for the isolation and purification of total lipids from animal tissues, J. Biol. Biochem. 226 (1957) 497-509.

[12] Fossati P., Prencipe L., Serum triglycerides determined colorimetrically with an enzyme that produces hydrogen peroxide, Clin. Chem. 28 (1982) 2077-2080.

[13] Fournier E., Peresson R., Guy G., Hermier D., Relationships between storage and secretion of hepatic lipids in two breeds of geese with different susceptibility to liver steatosis, Poultry Sci. 76 (1997) 599-607.

[14] Gandemer G., Pascal G., Durand G., Lipogenic capacity and relative contribution of the different tissues and organs to lipid synthesis in male rat, Reprod. Nutr. Dev. 23 (1983) 575-586.

[15] Gibbons G.F., Wiggins D., Brown A.M., Hebbachi A.M., Synthesis and function of hepatic very-low-density lipoprotein, Biochem. Soc. T. 32 (2004) 59-64.

[16] Griffin H.D., Butterwith S.C., Goddard C., Contribution of lipoprotein lipase to differences in fatness between broiler and layerstrain chickens, Brit. Poultry Sci. 28 (1987) 197-206.
[17] Hermier D., Forgez P., Chapman M.J., A density gradient study of the lipoprotein and apolipoprotein distribution in the chicken, Gallus domesticus, Biochim. Biophys. Acta 836 (1985) 105-118.

[18] Hermier D., Guy G., Guillaumin S., Davail S., Andre J.M., Hoo-Paris R., Differential channelling of liver lipids in relation to susceptibility to hepatic steatosis in two species of ducks, Comp. Biochem. Phys. B 135 (2003) 663-675.

[19] Hermier D., Saadoun A., Salichon M.R., Sellier N., Rousselot-Paillet D., Chapman M.J., Plasma lipoproteins and liver lipids in two breeds of geese with different susceptibility to hepatic steatosis: changes induced by development and force-feeding, Lipids 26 (1991) 331-339.

[20] Hermier D., Salichon M.R., Guy G., Peresson R., Differential channelling of liver lipids in relation to susceptibility to hepatic steatosis in the goose, Poultry Sci. 78 (1999) 1398-1406.

[21] Hsu R.Y., Lardy H.A., Malic enzyme, Method. Enzymol. (1969) 230-235.

[22] Lavau M., Bazin R., Karaoghlanian Z., Guichard C., Evidence for a high fatty acid synthesis activity in interscapular brown adipose tissue of genetically obese Zucker rats, Biochem. J. 204 (1982) 503-507.

[23] Leclercq B., Adipose tissue metabolism and its control in birds, Poultry Sci. 63 (1984) 2044-2054.

[24] Legrand P., Hermier D., Hepatic delta 9 desaturation and plasma VLDL level in genetically lean and fat chickens, Int. J. Obes. Relat. Metab. Disord. 16 (1992) 289-294.

[25] Lowry O.H., Rosebrough N.J., Farr A.L., Randal R.J., Protein measurement with the Folin phenol reagent, J. Biol. Chem. 193 (1951) 265-275.

[26] Mourot J., Guy G., Lagarrigue S., Peiniau P., Hermier D., Role of hepatic lipogenesis in the susceptibility to fatty liver in the goose (Anser anser), Comp. Biochem. Phys. B 126 (2000) 81-87.

[27] Pearce J., Some differences between avian and mammalian biochemistry, Int. J. Biochem. 8 (1977) 269-279.

[28] Pilo B., George J.C., Diurnal and seasonal variation in liver glycogen and fat in relation to metabolic status of liver and $\mathrm{m}$. pectoralis in the migratory starling, Sturnus 
roseus, wintering in India, Comp. Biochem. Phys. A 74 (1983) 601-604.

[29] Poujardieu R., Rouvier R., Rousselot-Pailley D., Guy G., Rosinsky M., Wezik S., Croissance et aptitude au gavage de 3 génotypes d'oies, Ann. Zootech. 43 (1994) 197211.

[30] Richmond W., Preparation and properties of a cholesterol oxidase from Nocardia sp. and its application to the enzymatic assay of total cholesterol in serum, Clin. Chem. 19 (1973) $1350-1356$
[31] Salichon M.R., Guy G., Rousselot D., Blum J.C., Composition des 3 types de foie gras : oie, canard mulard et canard de Barbarie, Ann. Zootech. 43 (1994) 213-220.

[32] Takayama M., Itoh S., Nagasaki T., Tanimizu I., A new enzymatic method for determination of serum choline-containing phospholipids, Clin. Chim. Acta 79 (1977) 93-98.

[33] U.I.C.P.A., Méthodes d'analyse des matières grasses et dérivés, 1979, 2.301. 